\title{
Limon Creole Phrases: A Vehicle for Linguistic and Cultural Preservation ${ }^{1}$
}

\section{(Frases de criollo limonense: vehículo para la conservación lingüística y cultural)}

\author{
Ginneth Pizarro Chacón ${ }^{2}$ \\ Universidad Nacional, Costa Rica
}

Damaris Cordero Badilla ${ }^{3}$

Universidad Nacional, Costa Rica

\begin{abstract}
Phrases and idiomatic expressions used in everyday speech in Limon Creole by a group of elderly people have been collected in the province of $\mathrm{Li}$ mon, Costa Rica, to preserve those phrases as part of their legacy to future generations. Considering the age factor, the information was gathered by applying a questionnaire to 50 native speakers of Limon Creole. Recommendations are provided, based on the results of the study.
\end{abstract}

\section{resumen}

Se recogen frases y expresiones idiomáticas del criollo limonense del habla cotidiana de un grupo de ancianos en la provincia de Limón, Costa Rica, con el fin de preservarlas como parte del patrimonio lingüístico regional. La información fue recolectada mediante un cuestionario a cincuenta informantes del criollo limonense, considerando el factor etario. Con base en los resultados del estudio se plantean recomendaciones pertinentes.

1 Recibido: 28 de febrero de 2015; aceptado: 30 de agosto de 2015.

2 Escuela de Literatura y Ciencias del Lenguaje. Correo electrónico: gpizarro@una.ac.cr

3 Escuela de Literatura y Ciencias del Lenguaje. Correo electrónico: Jodaro.damaris@gmail.com

$L_{\text {etras }} 58$ (2015), ISSN 1409-424X; EISSN 2215-4094 
Keywords: Limon Creole; idiomatic expressions; linguistic diversity; age factors Palabras clave: criollo limonense; expresiones idiomáticas; diversidad lingüística; criterios etarios

\section{Introduction}

Phraseological units are a common feature of languages; these expressions become used and recognized as representative elements of a culture. This is the case of Limon Creole, also known as Limon English or Mekatelyu, a language spoken in the province of Limon, on the Caribbean side of Costa Rica, as well as in Colon (Panama), Belize, and SanAndres. The term Mekatelyu is considered to be related to the English phrase "make I tell you" ("let me tell you"), and it was translated into Spanish as "déjame decirte." language, it has its own phonological patterns, grammatical structures and vocabulary, appropriate to the needs of its native speakers. It was introduced in Costa Rica by Jamaican immigrants who came to work on the banana plantations in Limon and on the Pacific railroad; for this reason, many Jamaican English words can be found in its lexicon.

Currently, there is an important gap between young and older generations speaking this language, because people feel more comfortable when speaking Limon Creole "only with family and a few other people," but not in public because it is considered "a broken language which may be disrespectful for those who do not understand it." This points to the importance of identifying the context and of preserving phrases that are used only by elderly people and not by the new generations.

4 Dora Vargas, “¿Qué es el mek-a-tel-yu?,” Revista Comunicación 2, 1 (1985): 113-142 (113).

5 Kenneth Mora, Hever Orias and Geraldine Zamora, "Limonese Creole" (research for Linguistics LLM419), Universidad Nacional, 2013; <https://prezi.com/mw1 wo3xczekx/limonese-creole/>. 


\section{Theoretical Background}

\section{Limon Creole}

Although Limon Creole (LC) has been considered a language, its syntax, phonology and lexicon have lost validity for some. It is restricted to family conversations, and used predominantly by adults or elderly speakers. Thus, one way to document and disseminate relevant aspects of this language is to collect phrases and expressions representative of this culture.

Since the beginning of the immigration of people from the Caribbean islands, English was the language spoken in Limon by the banana plantation administrators; as a result, Afro-Caribbean workers, in their minority status, had to adapt their linguistic ability to the dominant language, and this language became the main source of their lexicon. During the past century LC was also in close contact with Spanish, the official language of Costa Rica, and many Spanish words were incorporated into LC. ${ }^{6}$

Although Creoles have been affected by external influences, they conserve particular traits that make them unique. The majority of Caribbean Creoles are characterized by not having inflections in the verbs, meaning that the verb tenses are free morphemes that are closely related to their roots. Additionally, they share characteristics of Standard English (SE) in their lexicon.

Linguists such as Fernando Wright ${ }^{7}$ with research on LC syntax and Terry Wolfe ${ }^{8}$ with an exploratory study on its morphology and syntax, have shown that this variety has been a factor of identity for Limonese people and an important contribution to Costa Rican culture. The recovery of any of its linguistic features contributes to its preservation and diffusion through existing studies that have focused on LC

6 Anita Herzfeld, Mekaytelyuw: la lengua criolla. San José, Costa Rica: Editorial de la Universidad de Costa Rica, 2002), 165.

7 Fernando Wright, Limon Creole: A Syntactic Analysis (San José: Universidad de Costa Rica, 1974).

8 Terry A. Wolfe, "An Exploratory Study of the Morphology and Syntax of the English of the Province of Limon, Costa Rica,” Ph.D. dissertation, Universidad de Costa Rica, 1970. 
phonology, syntax, semantics and lexicon. However, phraseological studies on the use of specific words or phrases by elders have so far received comparatively less attention.

Wright pointed out that LC "is no longer seen as a serious means of communication in Limon because it is a language that has lost its primary function; that is, to allow communication among monolingual people." ${ }^{.9} \mathrm{He}$ also indicated some of the main characteristics of LC:

- Word endings are not conjugated.

- Vocabulary includes words borrowed from Spanish.

- Repetition of terms or words is frequent.

- There is no subject/verb agreement.

- There are no "be" form verbs.

- There is only one marker of time: "di."

- No forms of "do" are used in sentences.

- "Not" is only used to write negative sentences.

- At the phonological level, there are nineteen consonants, eight vowels and four diphthongs. ${ }^{10}$

LC consists mostly of Limon English features both in grammar and vocabulary; however, as Herzfeld has shown, Spanish has also affected it and made it difficult for it to survive. ${ }^{11}$ As Mufwene had stated earlier, creole development is influenced at some level by the languages of its first speakers: "Structural features have been predetermined to a large extent (but not exclusively!) by characteristics of the vernaculars spoken by the populations that founded the colonies in which they developed." 12 Mufene added: "The only influences in competition are structures of the lexifier and of the substrate languages; the language bioprogram or Universal Grammar, which need not be

11 Herzfeld.

12 Salikoko Mufwene, "The Founder Principle in Creole Genesis," Diachronica XIII (1996): 83-134 (84). 
conceived of as operating exclusively in children, regulates the selection of structural features from among the options in competition among the language varieties in contact."13

René Zúñiga provided additional historical background:

In 1949, the Costa Rican government decreed to give Costa Rican nationality to the people of Limon, and forced them to adopt Spanish as their official language. This "hispanizacion" increased the stigmatization of this language, and caused LC speakers to deny their linguistic identity. (. ) As a defense mechanism against this confusing scenario, speakers of this language "relegate further use, with the consequent danger of extinction." 14

LC researchers have focused their studies on its structures, language attitudes, grammar, and even on an alphabet. However, more research is required on the use of specific words or phrases by elders.

\section{Methodology}

Supported by a qualitative methodology, this research is defined as a case study which, according to Lopez, is "the empirical research of a phenomenon that you want to learn in an everyday real context." In a case study, a researcher knows a reality, and approaches it as convenience." ${ }^{15}$ Other authors such as Hernandez, Fernandez and Baptistaindicate that a case study corresponds to a description prepared by the researchers" ${ }^{16}$ with the use of ethnographic research to provide "a detailed, in-depth description that should be acknowledged as a

13 Mufwene, 89.

14 Rene Zúñiga Argüello, “QQué se habla en Limón?” (abstract of paper presented at the 17th Annual Eastern Caribbean Islands Cultures Conference, 2014) 40; our translation, <http://humanidades. uprrp.edu/ingles/wp-content/uploads/2014/10/Conference-Abstracts-2014.pdf>.

15 Wilmer Orlando López González, "El estudio de casos: una vertiente para la investigación educativa," Educere 17, 56 (2013): 139-144 (140).

16 Roberto Hernández, Carlos Fernández and Pilar Baptista, Metodología de la investigación, 6.a ed. (México: McGraw-Hill, 2014) 162-3. 
mutual product born of the interviewing of the lives of the ethnographer and his or her subjects, ${ }^{, 17}$ who in the present study corresponds to a group of elderly people in Limon.

Once the phrases were collected using ethnographic research, they were analyzed and documented, including the places where they are used registered. They were also translated into English and Spanish, and presented to a native LC speaker, who checked them one by one and gave recommendations for their correct spelling and written form. This research, therefore, was divided into two phases: a. The first phase focused on references related to LC and two personal interviews conducted Quince Duncan, an expert informant on LC and culture, and René Zúñiga Argüello, a linguist and LC researcher. They provided their perspectives on the use of the language, its progressive loss, and future revitalization. An instrument with open questions was designed for the interviews (see appendix 1). b. In the second phase data was obtained with another questionnaire which included open questions (see appendix 2). The data were obtained in downtown Limon from 50 informants whose ages range between 65 and 75 . They were selected since they use LC in their everyday speech and because of their desire to preserve the language. They were willing to cooperate with the study to help others understand the importance of speaking their language. Some had been contacted previously and others were chosen randomly. They were interviewed while at home, playing some games in the park, or chatting outside of a social club.

The main objective of documenting the fieldwork is to determine the relevance of having elders as representatives of LC linguistic transmission. This specific group may be viewed as a tool to spread the language among children, youngsters, and young adults. The present work serves to make those phrases known despite the younger generation's lack of interest.

17 Brian A. Hoey, "What is Ethnography?" (2008). Retrieved from <http://brianhoey.com/research/ ethnography/>. 


\section{Justification}

LC has been considered a language with distinct syntactic and phonological characteristics. A number of linguists have conducted research on LC. One of them is Marva Spence Sharpe, who carried out a study to determine if Limon people were bilingual or diglossic. ${ }^{18}$ Her findings helped clarify that the linguistic community in Limon was experiencing a linguistic change. Moreover, her research revealed that speakers in the Caribbean zone use more than one variety to communicate amongst themselves. This study has enabled researchers to realize that Limon is a bilingual and diglossic community, and three varieties must be used and taught: Spanish, SE, and LC.

Linguistic diversity has contributed to the limited use and spread of LC in Costa Rica. As a consequence, its syntax, phonology and lexicon are not relevant enough for generalized use, and it has been restricted to relationships amongst family and friends. It has generally been used by adults and elders who want to protect their heritage. One strategy to preserve this dialect and its idiosyncratic traits is to document all possible information related to phrases, their components and meanings. The context in which these phrases are used was also provided, to make both native speakers and non-native LC speakers aware of these phrases and their distinctive syntax and lexicon.

\section{Purpose of the Study and Research Questions}

The main purpose of this research is to collect LC phrases used by elders in their everyday life to emphasize the importance of preserving them as a legacy of linguistic and cultural traditions in Limon. This leads to the following research questions: 1 . What are some of the phrases LC speakers use?; 2. Who uses those phrases?; 3. In what 
context is each phrase is used?; and 4. Are those phrases restricted to family settings, friends, or public places?

\section{Further Contextualization}

As mentioned above, interviews were carried out with two different people - Qunice Duncan and René Zúñiga — to further contextualize the present study.

\section{Limon Creole: The Perspective Provided by Quince Duncan}

Quince Duncan, ${ }^{19}$ a well-known expert in LC language and culture, explained how to differentiate LC from bad English. In the past, speakers used British English at schools and church, and in formal situations, such as job interviews. In informal conversations on the street, they spoke "bad English"; however, they were not allowed to use this language or Spanish at home. Duncan referred to LC as an "idiolect or basilect," since it is difficult for native speakers of SE, or for speakers of English as a second language, to understand. He explained that $\mathrm{LC}$ is seen more as a language than a dialect by some speakers. He added that one reason to consider it a language is the fact that it is spoken all over Central America, Jamaica, Bluefields, San Andres, and even in Honduras.

Moreover, as stated by Kargleder, ${ }^{20}$ in the past, the Costa Rican government forced bilingual Limon speakers to suppress English in their daily conversations. It closed down Traditional English Schools (TES) because there were no certified teachers to teach SE. Consequently, the number of bilingual speakers diminished and was often confined to family settings. Therefore, according to Duncan, while some stopped using this language, others (between the ages of 45 and

19 Quince Duncan, Personal Interview. 13 April 2013; subsequent information and quotes are taken from this interview.

20 Charles Kargleder, “The Afro-Costa Ricans' Concept of Nationality as Reflected in Selected Works of Quince Duncan," paper presented at the XIX Latin American Studies Association (LASA) Congress, Washington D.C., 1995, <http://lanic.utexas.edu/project/lasa95/duncan.html>. 
50) tried to keep using Standard British English with a Caribbean accent. However, current reality is totally different; young people are gradually losing standard grammar and pronunciation, and they only speak Creole. This is because their Creole has been influenced by Spanish lexicon and syntax.

This Spanish influence became clear during President José Figueres Ferrer's administration. Spanish schools were established in Limon after the civil war, in response to the new conception of what being bilingual meant. President Figueres told Limon speakers:

...you cannot go back home because you never came from Jamaica; you were born in Costa Rica. So forget about going back home; if you do that, it will be easier for you to become Costa Rican. I can see that you receive a good education; you have your own system going. But there is no way in Costa Rica to have your own system in English; you have to learn Spanish (cited in Duncan ${ }^{21}$ ).

Duncan emphasized that the fact that the language was suppressed and the schools were closed. The government forced children to attend Spanish schools. That was the beginning of the loss of their bilingualism and some cultural traits reflected in that variety. LC has distinctive traits; by listening to $\mathrm{LC}$, one can perceive its close linguistic relationship with Jamaican Creole. Duncan says that this close relationship allows him to understand and speak Creole not only in Costa Rica, but also in Nicaragua and Panama. All those Creole languages have a similar syntax that makes them intelligible, and also dissimilar in grammar to SE. Duncan remarked that many LC phrases also come from African languages. His desire to expose teenagers to LC and its historical and linguistic legacy was accomplished through the publication "Descendencia en Costa Rica," written for teachers in Limon as a tool for their educational process. This booklet helped teach local linguistic and cultural traits since

$\overline{21}$ Quince Duncan, “El negro en la Costa Rica de hoy,” Revista del CESLA 7 (2005): 399-404 (403). 
the Costa Rican Ministry of Education only incorporated American culture in their English programs.

In face of that reality, Duncan questioned the policy of teaching only American English rather than Limonese Creole in the English courses. In the past, children and teenagers were exposed to British English as their first language, and Creole as the second one. They had the opportunity to hear both varieties at home and could understand them. Nowadays children and teenagers neither understand nor speak SE or Creole. Consequently, they prefer not to speak Creole and speak only Spanish. This results in the increasing number of monolingual speakers in Limon.

Finally, Duncan indicated that collecting those phrases and showing them to children and teenagers would be a way to teach their culture and identity to new generations. He also contends that one way to reverse the gradual loss of LC is by changing the syllabus and content of the courses in the public school system. With these programs, language teachers could adapt their subjects and class activities to linguistic traits and cultural aspects of LC.

\section{Limon Creole: the Perspective Provided by René Zúñiga Argüello}

Apersonal interview with René ZúñigaArgüello (UNAprofessor and linguist specializing in LC) provided another perspective about the position of LC in Costa Rica, its preservation, and the effort to spread its use among Limon citizens. He considers LC a language since it shows a systematicity different from other varieties of English. It has the structure of certain African languages, as well as syntax, including phonological traits and the vocabulary from English. That is why it looks so similar to English in lexicon. Another relevant fact to support this idea is mutual intelligibility. "If a person from the United States comes to Limon, he will probably understand a percentage of LC but not the entire conversation." ${ }^{22} \mathrm{He}$ reinforces that "LC corresponds to a

22 Rene Zuñiga, Personal Interview, Monday, June 20, 2016; subsequent quotes are taken from this interview. 
totally different system; to ask a question the order of the constituents is not altered the way it is done in English. In LC, the speaker alters the intonation; it is unnecessary to use auxiliaries or mark third person singular." He said that it is believed that speaking LC is using a "subversion of English," related to the simplification of the language. It is considered rule-governed; its intonation and rhythm are different and should be adopted by speakers. Its number of vowels is different from other varieties of English since Creole has five vowels and some Standard variants of English have 14, including the diphthongs.

In addition, he also clarified that black families speak Creole; if a black man marries a "paña" (a term originating from the word "Spaniard"), Creole will be spoken in that home because of a mixture in ethnicity. He added that LC has lost linguistic domains and is used mainly in closed environments such as family and friends. It is also used as a secret language among young people to communicate with those who speak Creole; they feel comfortable with one another when using Creole. They only speak Creole among themselves to be sure that other speakers do not understand the conversation. It is not used for formal conversations or in public places.

Zúñiga emphasized that the only way to preserve Creole is by teaching it to children. At present, children are forced to learn Spanish, so the only way to have them speak Creole is at home. Their grandmothers, who grew up speaking Creole, are the ones who preserve the language and teach them Creole. Before 1949, Limon people were bilingual, and spoke English and Creole; after 1949, they started speaking Spanish as well. Nowadays there is a bilingual population that speaks Spanish and Creole, but others speak only Spanish. Younger generations in Limon are attending English classes to learn a language spoken by their ancestors. They do not speak Creole; they are more interested in learning SE.

It is important to clarify that the first generation, the Jamaicans who originally came to Limon, used British in formal settings and avoided Creole because it was considered "a wrong version ofEnglish." 
The second generation is closer to Creole and uses it in informal settings. The third generation rejects Creole and does not consider it part of their speech. Zúniga emphasizes that there is a dilemma regarding the perception people from Limon have about Creole; some defend Creole and others do not. Zúniga added that at present a number of individuals, organizations and religious authorities are supporting Universidad Nacional (UNA) researchers who are working in projects to give "status to the language."

Since Creole has been stigmatized by outsiders and insiders, speakers are convinced that they should not speak Creole. They see it as a wrong version of a language and recognize that it will not help them find a job; thus there is no reason to spend time learning it instead of other languages. Young people believe that the domain of Creole is reduced to family environment and that it is not useful. Moreover, it is not recognized by the Costa Rican government as a language, nor officially taught in state schools. On the other hand, SE is taught in those schools by non-native speakers of English who do not speak Creole either. This has restricted the spread of Creole.

Zúñiga also added: "UNA researchers are working on a descriptive grammar and pedagogical strategies to teach Creole. The university will open an elective course to teach Creole to the students who are interested in the language, being this course is the first attempt to teach the language formally." He also mentioned other initiatives such as that of the "Universidad de Costa Rica as the first to conduct research related to LC structures and language attitudes." At UNA, his team has worked on a grammar of the language and an alphabet to allow people to write the language. They are also promoting a bill in congress to include Limon in article 76 as part of the constitution and declare it as part of Costa Rica's national patrimony." He reaffirms that UNA has given him a lot of support to develop his projects and preserve Creole. He is currently promoting Creole in Limon to enable people to understand the importance of speaking their language. After seven years, his effort to give Limon Creole its due relevance 
is paying off so that the possibility of saving Creole from extinction can become a reality.

\section{A Progressive Loss: Possible Reasons}

Every generation possesses distinctive traits that make it unique and those traits can be shown in cultural and linguistic manifestations. Each manifestation defines not only group characteristics, but also individual ones. Accordingly, each speaker will transmit his or her idiosyncratic traits in terms of rituals and language; this is because a language shows variability in its phonology, syntax, semantics and pragmatics, and these aspects make languages particular. Among those languages, Limon Creole (LC) displays a great variety of linguistic features that distinguish it from other languages, and since this language is only spoken in the province of Limon, its use and transmission is restricted to a reduced number of speakers. This restriction has caused this language to lose relevance for them in Limon, as they are replacing it by Spanish or American English. This progressive loss has been the result of a number of problems and challenges that the language has faced for many years, and some of the main reasons why this situation is prevalent are summarized below:

a. Although most parents encourage their children to speak LC at home, they refuse to do so. They prefer to speak Standard American English because it is considered prestigious and well known worldwide. Consequently, they lose the Limon accent and linguistic traits. In some cases, parents punish their children if they do not speak LC; however, this is not enough to make them use the language.

b. At elementary and secondary schools, language instructors teach American English; consequently, students do not come in contact with LC. 
c. In other cases, parents address their children in LC, but they reply in Spanish. The use of Spanish at home and school has become generalized among children and teenagers. Since it is the dominant language, it has a strong influence upon Limon speakers.

d. Some parents send their children to English classes for them to learn SE, or what they call "real English," and they usually learn American English.

e. People feel ashamed of using Creole in public places; its use is restricted to family conversations at home or meetings among friends, but they prefer to use another language, such as Spanish (or SE), because they want to be accepted by their peers and follow society's rules in regards to the language that they must use.

f. Some parents address their children in Spanish even though they speak LC. Consequently, children do not get used to speaking Creole and perceive it as a relic of their parents' life. Thus, cultural traits transmitted through the language are lost.

g. In most cases, elementary and high school language instructors teach SE rather than Creole. LC is not included in students' curriculum since it is not considered a language in the Costa Rican constitution. Children, therefore, have no contact with LC and its cultural traits.

h. In Limon, children are speaking neither SE nor LC, so they became monolingual; and this is a disadvantage for them in their development in a competitive multilingual society, because in the past, their parents and grandparents attended Traditional English Schools (TES), which taught them British English, and Spanish Schools. This type of education made them bilingual with more job opportunities and a higher position on the social scale.

i. Finally, some family members continue using LC in daily conversations as a way to preserve it; however, others in the same family do not use it at all, although they do understand it. 
This progressive loss has affected the prevalence of LC as a linguistic and cultural representation of a particular geographical region: Limon. University researchers, however, are working on strategies to preserve and revitalize the language.

\section{Overview of the Findings}

The second part of this investigation was aimed at collecting all possible information (the corpus) through interviews conducted in downtown Limon in informal settings such as houses, parks, and a social club. Each interview was recorded and transcribed by the researchers, and some sample phrases were provided by 50 people whose age ranges from 65 to 75 years old. Once the information was collected, the researchers created a list of phrases, sentences, and idiomatic expressions that the elders use when they are chatting at home, meeting with close friends, or having a casual conversation with an acquaintance that speaks LC. The list of phrases collected were checked and validated by the English teacher Ruth Edwards, an UNA graduate who is a native Limon Creole speaker.

A number of proverbs and expressions have already been collected and published elsewhere in Marta Johnson's book, Granny True Words. ${ }^{23}$ In her work, she rescues Afro-Caribbean proverbs that portray Limon Creole traits that are gradually becoming lost. In the present research, however, based on the fact that $\mathrm{LC}$ must be recovered as a means of communication among Limon speakers, it was deemed important to collect the everyday LC expressions of elderly informants during the interviews as indicated above. After they were transcribed, they were translated into SE and into Spanish (table 1) for a clearer understanding of national and international readers. 
Table 1. Limonese Creole expressions collected during interviews

\begin{tabular}{|c|c|c|}
\hline Limonese Creole & Standard English & Spanish \\
\hline A woz sik & I was sick & Yo estuve enferma... \\
\hline $\begin{array}{l}\text { An mi kozin se "aarayt! } \\
\text { Fayt don! }\end{array}$ & $\begin{array}{l}\text { And my cousin said, } \\
\text { "Alright, the fight is over!" }\end{array}$ & $\begin{array}{l}\text { Y mi primo dijo, "Bien, se } \\
\text { terminó la pelea", }\end{array}$ \\
\hline ...an wen im liv... & ... and when he leaves... & ...y cuando se va.... \\
\hline $\begin{array}{l}\text {...an wyet, antil wen it } \\
\text { byek... }\end{array}$ & $\begin{array}{l}\text {... and wait until it is } \\
\text { baked... }\end{array}$ & $\begin{array}{l}\text {...y espera hasta que esté } \\
\text { cocido... }\end{array}$ \\
\hline Ay dwon biliv dat... & I don't believe that... & No puedo creer eso... \\
\hline Ay dwon layk dat... & I don't like that... & No me gusta eso... \\
\hline Ay dwon min tu se... & I don't mean to say... & No quiero decir eso... \\
\hline Ay dwont drink mi pus mit & I'm not a fool & No soy un tonto/iluso \\
\hline Ay get beks... & I became upset... & Me enojé... \\
\hline Ay woz worid & I was worried & Yo estaba preocupada... \\
\hline Bak to skuw... & Back to school... & Volver a la escuela ... \\
\hline Beta now an fors taym & $\begin{array}{l}\text { Better now than the first } \\
\text { time }\end{array}$ & $\begin{array}{l}\text { Mejor ahora que la primera } \\
\text { vez. }\end{array}$ \\
\hline Born wer? & Born where? & ¿Dónde nació? \\
\hline $\begin{array}{l}\text { Bot a lis yu byeyv gud an di } \\
\text { strit an aal dem tin... }\end{array}$ & $\begin{array}{l}\text { But at least you behaved } \\
\text { good on the street and all } \\
\text { those things }\end{array}$ & $\begin{array}{l}\text { Por lo menos te portabas } \\
\text { bien en la calle y esas cosas }\end{array}$ \\
\hline Dat buk iz mi won & That's my book & Ese es mi libro \\
\hline Dat shi won byebi & That is her baby & Ese es el bebé de ella \\
\hline Dat wan fi mi & That one is for me & Ese es para mí \\
\hline De dota, im tel mi... & The doctor, he told me... & El médico me dijo... \\
\hline De milk kot op & The milk curdled & Se cortó la leche \\
\hline De partna kom in... & The partner comes in... & El compañero entra... \\
\hline De son shayn... & The sun shines... & El sol brilla... \\
\hline Dem buk foni & Those books are funny & Esos libros son cómicos \\
\hline Dem en a laaf afta mi & They were laughing at me & Se estaban riendo de mí \\
\hline Dem put yu in a layn so... & They put you in a line so... & Te ponen en una fila así... \\
\hline $\begin{array}{l}\text { Dem tel mi se dem neba si } \\
\text { yu yet }\end{array}$ & $\begin{array}{l}\text { They told me that they have } \\
\text { not seen you yet }\end{array}$ & $\begin{array}{l}\text { Ellos me dijeron que no te } \\
\text { han visto aún... }\end{array}$ \\
\hline Dey gow taylet... & They went to the toilet... & Ellos fueron al inodoro... \\
\hline Di buk dem & The books & Los libros \\
\hline
\end{tabular}




\begin{tabular}{|c|c|c|}
\hline Limonese Creole & Standard English & Spanish \\
\hline Di bway dem & The boys & Los niños/muchachos \\
\hline Di byebi ogli & The baby is ugly & El bebé es feo \\
\hline Di uman byebi & The woman's baby & El bebé de la mujer \\
\hline $\begin{array}{l}\text { Diay! If yu woz tu ded, you } \\
\text { ded }\end{array}$ & If you were to die, you die & $\begin{array}{l}\text { Diay, si te tuvieras que } \\
\text { morir, te morís }\end{array}$ \\
\hline Dwont ful rownd & Don't waste your time & No desperdicie el tiempo \\
\hline Dwont molest & Don't bother me & No moleste \\
\hline Dwont taak a nays in pi & It's too disgusting & Es desagradable \\
\hline Dyam kryebin & $\begin{array}{l}\text { Eat like a horse/ eat one's } \\
\text { fill }\end{array}$ & $\begin{array}{l}\text { muerto de hambrelque } \\
\text { come más de la cuenta }\end{array}$ \\
\hline Eni taym yu taak... & Any time you talk... & Cada vez que usted habla... \\
\hline Es ke ay di waa gow in... & I wanted to go into... & Es que yo quería ir a... \\
\hline Fala fachin monki. & $\begin{array}{l}\text { To be envious/You want } \\
\text { something someone else } \\
\text { bought }\end{array}$ & $\begin{array}{l}\text { Ser envidioso/Querer algo } \\
\text { que otra persona compró } \\
\text { o posee }\end{array}$ \\
\hline Fayt don & The fight over... & Se terminó la pelea... \\
\hline $\begin{array}{l}\text { Fi ignorant an a dwon spiki } \\
\text { to noadi }\end{array}$ & $\begin{array}{l}\text { Felt upset and I didn't speak } \\
\text { to anybody }\end{array}$ & $\begin{array}{l}\text { Me sentía enojada y no } \\
\text { hablaba con nadie }\end{array}$ \\
\hline From wen wapil kil filop & Old fashioned & Pasado de moda \\
\hline Go dye! & Good day! & ¡Buen día! \\
\hline Gud ivnin! & Good evening! & ¡Buenas noches! \\
\hline Gud marnin! & Good morning! & ¡Buenos días! \\
\hline Im did mari wid mi fren & He married my friend & El se casó con mi amiga \\
\hline Im iz mi faada & He is my father & Él es mi padre \\
\hline Im kom lyet, downt it? & He came late, didn't he? & ¿Llegó tarde, no es cierto? \\
\hline Im no now & He doesn't know & Él no sabe \\
\hline Im no waan it & He doesn't want to eat & Él no quiere comer \\
\hline In Ogos ev laas ye & In August of last year... & En agosto del año pasado... \\
\hline It afi kot... & It has to be cut... & Tiene que ser cortada... \\
\hline Iyvin fi gow owtsay... & Even to go outside... & Incluso para salir... \\
\hline Iz dyer ay work... & Is that where I work... & Es alli que trabajo... \\
\hline Iz jes de it de... & It is just there.... & Es justo ahí... \\
\hline Iz so ay layk it... & It is so I like it... & $\begin{array}{l}\text { Es de esta manera que me } \\
\text { gusta... }\end{array}$ \\
\hline
\end{tabular}




\begin{tabular}{|l|l|l|}
\hline \multicolumn{1}{|c|}{ Limonese Creole } & \multicolumn{1}{|c|}{ Standard English } & \multicolumn{1}{c|}{ Spanish } \\
\hline Iz tiif dem tiif it & It was certainly stolen & $\begin{array}{l}\text { Son ladrones los que se lo } \\
\text { robaron }\end{array}$ \\
\hline Kip as qwai! & Let's keep quiet! & $\begin{array}{l}\text { iMantengámonos en } \\
\text { silencio! }\end{array}$ \\
\hline Kom hay bway! & Come here boy! & ¿Venga aquí muchacho! \\
\hline Kom mi bway & Come with me, boy & Venga, joven. \\
\hline Kom ya & Come here & Venga \\
\hline Kom yer bway & Come here boy & Ven, muchacho \\
\hline Man cow & The man's cow & La vaca del hombre \\
\hline Mi a gran pupa... & I am a grandfather... & Yo soy un abuelo... \\
\hline Mi dis iyt don & I just finished eating & $\begin{array}{l}\text { Acabo de terminar de } \\
\text { comer }\end{array}$ \\
\hline Mi fada iz workin & My father is working & Mi padre está trabajando \\
\hline Mi fut swell & My feet swelled up & Se me hincharon los pies \\
\hline Mi gan owm, ron & I ran home & Corrí a casa \\
\hline Mi go san xose tamara & $\begin{array}{l}\text { I am going to San Jose } \\
\text { tomorrow }\end{array}$ & Voy a ir a San José mañana \\
\hline Mi neba now im & I don't know him & No lo conozco \\
\hline Mi won & My own & Lo mío \\
\hline Ñam an gow. & $\begin{array}{l}\text { I'll stay just for dinner and } \\
\text { leave; eat and run }\end{array}$ & $\begin{array}{l}\text { Indio comido puesto al } \\
\text { camino }\end{array}$ \\
\hline Neks wik wi go mek & Next week we will make... & $\begin{array}{l}\text { La semana próxima lo } \\
\text { haremos... }\end{array}$ \\
\hline Nwo wat... & Know what... & Sabía que. \\
\hline $\begin{array}{l}\text { Ow moch taym sins you liv } \\
\text { in Limon? }\end{array}$ & $\begin{array}{l}\text { How long have you lived in } \\
\text { Limon? }\end{array}$ & $\begin{array}{l}\text { ¿Cuánto tiempo hace que } \\
\text { vive en Limón? }\end{array}$ \\
\hline Ow moch yer yuw av? & How old are you? & ¿Cuántos años tienes? \\
\hline Ow mosh a clat? & What's going on? & ¿Qué sucede? \\
\hline Ow mosh ay klat bway? & What time is it? & ¿ué hora es? \\
\hline Papi shwo & You act like a clown/ & $\begin{array}{l}\text { Actúa como un payaso. } \\
\text { Actúa ridículamente. }\end{array}$ \\
\hline Ron go lef im & $\begin{array}{l}\text { Run, go leave him/run away } \\
\text { from him }\end{array}$ & $\begin{array}{l}\text { Corra, vaya déjelo/ aléjese } \\
\text { de él corriendo }\end{array}$ \\
\hline Ryen a faal & Rain is falling & La lluvia está cayendo \\
\hline Shi rayt aal di taym... & She writes all the time... & $\begin{array}{l}\text { Ella escribe todo el } \\
\text { tiempo... }\end{array}$ \\
\hline
\end{tabular}




\begin{tabular}{|c|c|c|}
\hline Limonese Creole & Standard English & Spanish \\
\hline Shi wok at de haspital... & She works at the hospital... & Ella trabaja en el hospital \\
\hline Sho-cho! & $\begin{array}{l}\text { Disgusting/ Something } \\
\text { horrible someone did. To } \\
\text { be upset about someone's } \\
\text { behavior }\end{array}$ & $\begin{array}{l}\text { Repugnante/Estar indispuesto } \\
\text { por algo que alguien hizo }\end{array}$ \\
\hline Sins ay in Limon ye... & $\begin{array}{l}\text { Since I have been here in } \\
\text { Limon... }\end{array}$ & $\begin{array}{l}\text { Desde que yo estoy aquí en } \\
\text { Limón... }\end{array}$ \\
\hline Wa yu du? & What do you do? & ¿Qué hace? \\
\hline Wa yu wan? & What do you want? & ¿Qué quiere usted? \\
\hline Waapin? & $\begin{array}{l}\text { What's happening?/What's } \\
\text { up? }\end{array}$ & $\begin{array}{l}\text { ¿Qué sucedel¿Qué hay de } \\
\text { nuevo? }\end{array}$ \\
\hline Wat's gwain an? & What's going on? & ¿Qué sucede? \\
\hline We di plyes nyem de? & $\begin{array}{l}\text { What is the name of the } \\
\text { place? }\end{array}$ & $\begin{array}{l}\text { ¿Cuál es el nombre del } \\
\text { lugar? }\end{array}$ \\
\hline Wel datde woz a gud tin & Well, that was a good thing & Bien, esa es una buena cosa \\
\hline Wen a woz smaal... & When I was small... & Cuando yo era pequeña... \\
\hline Wer yu bin? & Where have you been? & ¿Dónde has estado? \\
\hline Wer yu der? & Were you there? & ¿Estabas ahí? \\
\hline Weray go? & Where do I go? & ¿Dónde iré? \\
\hline Wi a taak bowt ... & We are talking about... & Estamos hablando de... \\
\hline Woz wan marnin & It was one morning... & Fue una mañana... \\
\hline You andestan? & Do you understand? & ¿Entiende? \\
\hline Yu ar no a Spanish pyepa & $\begin{array}{l}\text { You are not behaving } \\
\text { according to your age }\end{array}$ & $\begin{array}{l}\text { No se comporta de acuerdo } \\
\text { a suedad }\end{array}$ \\
\hline Yu bi gud & You are good & Usted es bueno \\
\hline Yu dwon toch it... & Don't touch it... & No lo toque... \\
\hline Yu fownd der & You were found there & Usted fue encontrado allí \\
\hline Yu gat tu pye... & You got to pay... & Usted tiene que pagar... \\
\hline Yu gow retar im! & You go challenge him! & ¡Vaya, rételo! \\
\hline Yu mosimad & You must be mad & Usted debe estar furioso \\
\hline Yu now im? & Do you know him? & ¿Lo conoces? \\
\hline Yu profamin & You're pretending & Usted finge lo que no es \\
\hline
\end{tabular}


According to Ruth Edwards, ${ }^{24}$ this list of phrases "reflects Limon people's everyday speech among family members, friends or acquaintances."Each phrase shows specific phonologicaland syntactic traits that are related to some other Caribbean Creole languages, and they are examples of particular linguistic manifestations of certain syntactic traits that differentiate LC from English. Some people insist on comparing LC with SE, as they perceive LC as a dialect. However, "Limon Creole has syntactic structures based on some African languages, although the lexicon is quite similar to English" (Zúñiga, personal interview). This difference can be observed in the corpus; for example:Mia gran pupa ...(I ama grandfather...), and Dei gow toylet... (They went to the toilet...). Here, in comparison with SE usage, the lack of the main verb in the first case, and the use of a present-tense verb instead of the past tense, in the second show particularities that can point to Limon Creole being a separate language. The similarity between SE vocabulary and words such as pupa and toylet is simply the result of borrowing from the English lexicon.

Another relevant aspect that can be observed in the corpus is the different arrangement of the words when compared to SE. For example, Dat buk iz miy wowhn in which the subject is "that book" and the complement is "my book." On the other hand, "that's my book" shows the demonstrative pronoun as a subject and "my book" as a complement. That different word order can provide support for the idea that Limon Creole is a language that is not easily understood by SE speakers. They believe that great inventiveness is evident in those phrases. They convey Limon speakers' worldview and cultural traits that can be related to their ordinary events on a daily basis. The informants mentioned they feel comfortable when they communicate with others using Limon Creole because "pañas"(whitepeople) cannot know what they are talking about. This second generation of speakers

24 Ruth Edwards, Personal interviews (2014). 
(elders) perceives their language as part of their heritage since they were taught by their parents and grandparents.

Furthermore, most of the informants feel disappointed with the idea that LC usage among the members of the community is disappearing because younger generations and even middle-aged people do not want to use it. Youngsters do not see it as part of their life; on the contrary, they want to learn another language, particularly English, to avoid being discriminated against in a society that sees Limon Creole as a non-prestigious language. Thus, LC number of speakers is gradually diminishing since they have been indirectly forced by external circumstances to reject their own language. Limon Creole must be seen as a prestigious language in Limon since it is part of their legacy and heritage. People must not be ashamed of speaking it in public places; on the contrary, they must be proud of using and sharing a language that is so rich in linguistic diversity and culture.

\section{Recommendations}

To preserve Limon Creole phrases used by elders in the province of Limon as well as to teach the language is a priority in Costa Rican linguistic development, but as Duncan adds, "gradually, many of those phrases are being forgotten by a large number of speakers because there are not enough researchers to collect, preserve and teach Limon Creole to new generations. ${ }^{.25} \mathrm{He}$ mentions that one reason why Limon Creole is being lost is because most of the teachers in elementary schools and high schools are white. Although teachers expand students' view of the world and introduce them to new topics, they have taken their cultural identity away." ${ }^{26}$ This fact coupled with a constant rejection of the language by Limon speakers have reduced the number of Limon Creole speakers. To halt this process,

25 Duncan (2005), 400.

26 Duncan (2005), 400. 
recommendations can be provided to keep those phrases alive as part of Creole; it is essential to:

a. realize that elders are vehicles to transmit those phrases and that a joint effort must be made to collect those phrases for a phraseology dictionary;

b. encourage English teachers and professors of linguistics to include that information as part of their syllabus in phonetics, phonology, morphology, and semantics courses;

c. enable the Ministry of Education to understand the relevance of revitalizing the language and include it in students' curriculum; and

d. foster local and national newspapers to publish more about research done on this topic in order to inform Limon Creole speakers and non-speakers.

\section{Conclusions}

An awareness of the relevance of any language or any other manifestation of English in the English-speaking community must be raised among members of a society. An acceptance and respect towards differences in languages will allow speakers of diverse languages to feel empowered to use any variant not only at home, but also in public. Speakers will thus learn to preserve and transmit the language for future generations without perceiving it as less prestigious. Unfortunately, this positive view is not held by all speakers who believe that their language is not as prestigious as other languages; consequently, the language is losing relevance and its use has been reduced to family settings or chats with friends.

Limon Creole has suffered a gradual decrease in the number of those who speak it or who are exposed to it, so the elderly see fewer opportunities of speaking LC in their homes and communities. With the survey carried out here, information was collected about phrases 
and expressions that the subjects use at home or with friends, along with some reactions about the negative implications that the lack of usage of LC has on the community of speakers and the language itself. This information provided examples of phrases and expressions used in everyday activities or conversations. The informants emphasized that those words are closely related to their family traits, culture, and identity as a group. Their daily use makes Limon people feel part of a community whose traits differentiate them from other Costa Ricans.

The future looks uncertain for those who want to preserve LC, because younger generations and the middle-aged are not interested in speaking LC. On the contrary, they are learning American English in private institutions, elementary and secondary schools, or they simply speak Spanish. This contrasts with the past when Limon speakers were bilingual since they attended English Traditional Schools whose teachers came from Jamaica. Many have reduced their contact with the language and have become passive listeners or monolinguals. That reduces their opportunities in a society that favors bilingualism and opens doors to better job opportunities and social conditions.

This conscious rejection ofLCis reducing the number of speakers and the use of those phrases and expressions. The outlook for LC is not encouraging; elders are passing away and their linguistic legacy is disappearing. Even though LC seems condemned to disappear, some external efforts to revitalize Creole are being made: the Universidad de Costa Rica (UCR) and Universidad Nacional (UNA) are making a significant effort through different projects in Limon. UCR was a pioneer in research on Limon Creole structures and language attitudes; the UNA project "Prolinca" has prepared a grammar of the language and an alphabet.

In addition, as mentioned above, the UNA project is promoting a bill in the national congress to include Limon in article 76, as a language spoken in Costa Rica. Certain policies inside the family can also be fostered. First, parents and grandparents can encourage youngsters to speak the language, by teaching them its relevance as a 
vehicle to preserve family traditions and idiosyncratic words. Second, the government must hire native Creole speakers to teach the language in primary and secondary school; Creole should be included in the curriculum as a way to transmit linguistic and cultural traits. In this way, learners will become bilingual (Creole and Spanish). This effort could have a positive cultural impact on the linguistic community and on the preservation of LC. 


\section{Appendix 1}

\section{Questionnaire No. 1 (used with experts)}

The following instrument will be used to collect information in an interview conducted with an expert on Limonese Creole regarding the relevance of elders' usage of idiosyncratic Limon Creole phrases in their daily activities or events.

Expert's name:

Educational level:

Years studying Limonese Creole:

\section{Relevance of Limonese Creole}

a. Why is Limon Creole so distinctive and unique when compared to some other English Creoles?

b. What are some distinctive traits that make Limon Creole particular?

c. Has this variety received the credit it deserves?

\section{Idiosyncratic Phrases}

a. What are some of the phrases you remember your grandmother using at home, among friends or in public?

b. Were those phrases restricted to a particular setting or context?

c. Why should those phrases be collected, analyzed and taught to younger generations?

d. Could you give me some recommendations regarding how to preserve those phrases as representations of a culture and their speakers? 


\section{Appendix 2}

\section{Questionnaire No. 2 (used with informants)}

The instrument below will be used to collect information about idiosyncratic phrases elders in the province of Limon use to refer to everyday activities or events. These phrases show outstanding linguistic features of Limonese variety and its people. This information will provide enough findings to give social aspects, some semantic and syntactic aspects, and recommendations.

Informant's name:

Age:

Educational level:

Geographical area:

\section{Cultural Traits}

a. What does Limonese Creole represent for you?

b. Has Limonese Creole changed with time? Why?

c. Has Limonese Creole been kept as the first variety in everyday speech among families in the province of Limon?

\section{Limonese Traits}

a. What are some of the phrases that identify Limonese Creole in your family conversations?

b. How often do you use those phrases at home? Is there a specific setting where they are used?

c. Are teenagers interested in learning those phrases? Why?

d. What are parents doing to transmit the legacy of this variety? 


\section{Preservation of the phrases}

a. How can these phrases be preserved and taught to younger generations?

b. Are Limon elementary schools and high schools doing anything to spread the use of those phrases in classroom activities?

Thank you for your help with this project. 